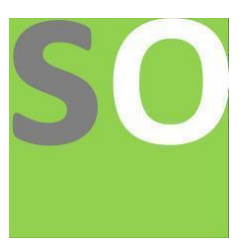

Article title: Simulation and Control of Virtual Power Plant for Effective Utilization of Distributed Generation Authors: Tushar Machhi[1]

Affiliations: CHIRAG BUNGLOW NEAR WATERTANK NANABAZAR VV NAGAR[1]

Orcid ids: 0000-0001-9555-1232[1]

Contact e-mail: tusharmachhi13@gmail.com

License information: This work has been published open access under Creative Commons Attribution License $\mathrm{http}: / / c r e a t i v e c o m m o n s . o r g / l i c e n s e s / b y / 4.0 /$, which permits unrestricted use, distribution, and reproduction in any medium, provided the original work is properly cited. Conditions, terms of use and publishing policy can be found at https://www.scienceopen.com/.

Preprint statement: This article is a preprint and has not been peer-reviewed, under consideration and submitted to ScienceOpen Preprints for open peer review.

Links to data: 1. H. A. Khan, H. C. IU and V. Sreeram, "Active and Reactive Power Control of the Electronically Interfaced DG Sources for the Realization of a Virtual Power Plant"IEEE Industrial Electronics Society Nov.2011.

DOI: 10.14293/S2199-1006.1.SOR-.PPDU4JE.v1

Preprint first posted online: 16 January 2022

Keywords: solar PV, wind mill, fuel cell, grid tied, inverter, virtual power plant, micro grid 


\title{
Simulation and Control of Virtual Power Plant for Effective Utilization of Distributed Generation
}

\author{
Mr. Tushar J. Machhi \\ M.E, Power System \\ Dept. of Electrical Engg. \\ GCET
}

\author{
Prof. Chintan R. Patel \\ Assistant Professor \\ Dept. of Electrical Engg. \\ GCET
}

\author{
Dr. Ritesh R. Patel \\ Professor \\ Dept. of Electrical Engg. \\ GCET
}

\begin{abstract}
With the growing popularity of virtual power plant, few problems are encountered if penetration of virtual power plant increases in the distribution network like reverse power flow, interference caused with the controlling mechanism of voltage regulating devices, power quality issues at the PCC which are caused by irregular and unreliable injection. This project proposes an alternative injection strategy for decentralized virtual power plant in the distribution network. This strategy lets the virtual power plant act like a typical power plant and makes the system capable to regulate its terminal voltage by injecting only the required power. Such type of predictive injection lets an easy coordination between control mechanisms of various voltage regulating devices and reduces power quality issues. Also virtual power plant can be operated as a small base load plants which inject power throughout the day and/or supply few hours of peak load depending on the adopted injection strategy. Another advantage is the creation of a small micro grid. A design example of the proposed system is discussed in this project.
\end{abstract}

Key words: solar PV, wind mill, fuel cell, grid tied, inverter, virtual power plant, micro grid

\section{INTRODUCTION}

Virtual power plant is an aggregation of distributed energy resources units disperse among the network but controllable as a whole generating system. They are controlled by a central authority and can include natural gas-fired reciprocating engines, small scale wind power plant, photovoltaic, run of river hydroelectricity plants, small hydro, biomass, backup generators and energy storage systems. The control paradigms of the DG sources in the smart grid are realized by either utilizing virtual power plant structures or by employing micro grid structures. Both virtual power plant and micro grid are presented with the problem of control of power flow between their comprising DG sources. In this paper $\mathrm{H}$. A. Khan Provided control methodology for the control of active and reactive power in the virtual power plants [1]. In this paper Xavier Dominguez use the DC bus for the integration 
of the different distributed generators and the storage system. Different DC-DC power converters schemes have been employed to fulfill this goal. Later, by means of an Energy Management System strategy which commands a three-leg three phase inverter having a suitable modulation technique, the control of the demanded active power is performed.

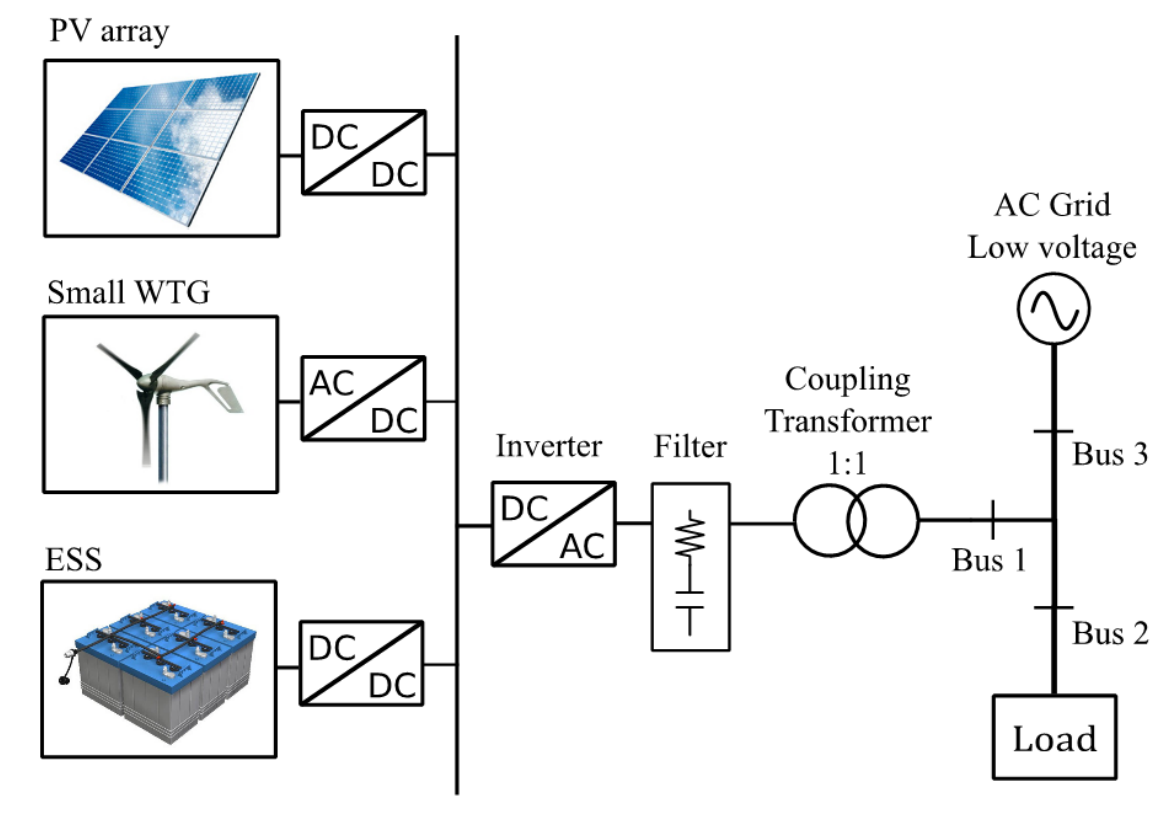

Fig. 1. Proposed VPP connection and integration scheme

In EMS strategy the total DG power and the load's demanded power are verified. Depending on this comparison, the battery state of charge and the battery's maximum charge and discharge power, the injected (negative) or extracted (positive) power from the grid and the battery are calculated [2]. The Lucian Ioan DULĂU describes the main characteristics of distributed generation (DG) and Virtual Power Plants (VPP) and the VPP is tested for different merit order values and grid connections (on-grid and off-grid) to track if this order is respected [3]. In this paper Setu Paghdar power flow control has been achieved by PWM switching control of a 3-phase VSC, which is made to follow the real-time grid frequency always and remain in synchronization with the grid. In the experiment, the phase angle and modulation index of converter are varied alternatively. The effects of different phase angles $(\delta)$ and modulation index $(m)$ on active power $(P)$ and reactive power $(Q)$ is control [4]. In this paper Veera Joshi used vector control strategy for active power and the reactive power control independently via control of voltage source inverter [5]. In this paper Jose Restrepo develop direct power control techniques to inject the active and reactive power into grid [6]. 


\section{System Adopted}

\subsection{Problem}

In a distribution network, the voltage across feeder drops when load increases so devices such as voltage regulators, on load tap changing transformers, etc. which regulate the voltage are used to maintain voltage profile of the feeder. Currently virtual power plant incorporated in distribution network inject power at a fixed power factor of unity to get the maximum economic benefit. Now if the penetration of such virtual power plant increases, they produce following difficulties.

1) A portion of load will be supplied by the virtual power plant so the feeder current will decrease which will reduce the voltage drop so the voltage at the end of feeder may increase during high injection and may fall if control mechanisms of voltage regulating devices are not adjusted with decrease in injection of virtual power plant.

2) The weather conditions have a noticeable impact on the injection of virtual power plant and the injection also varies throughout the day. Therefore, it becomes difficult to coordinate the controlling mechanism of voltage regulating devices with virtual power plant injection to maintain a stable voltage profile on the feeder.

The traditional grid, which is not designed for such type of injection may limit the penetration of such virtual power plant which is not desired.

\subsection{Solution}

The problems discussed above can be solved if virtual power plant could act like a conventional power plant which injects active power according to the demand and regulates the voltage supplying necessary reactive power.

The strategy discussed in this paper can be applied to new residential/office complexes. In the existing virtual power plant of a society or a locality can be clubbed and then a central control can be provided. By incorporating batteries, unreliable renewable energy resources 
can be transformed into a highly reliable small power plants capable of injecting power throughout the day. The design of such system is discussed in this paper.

\subsection{Single Line Diagram}

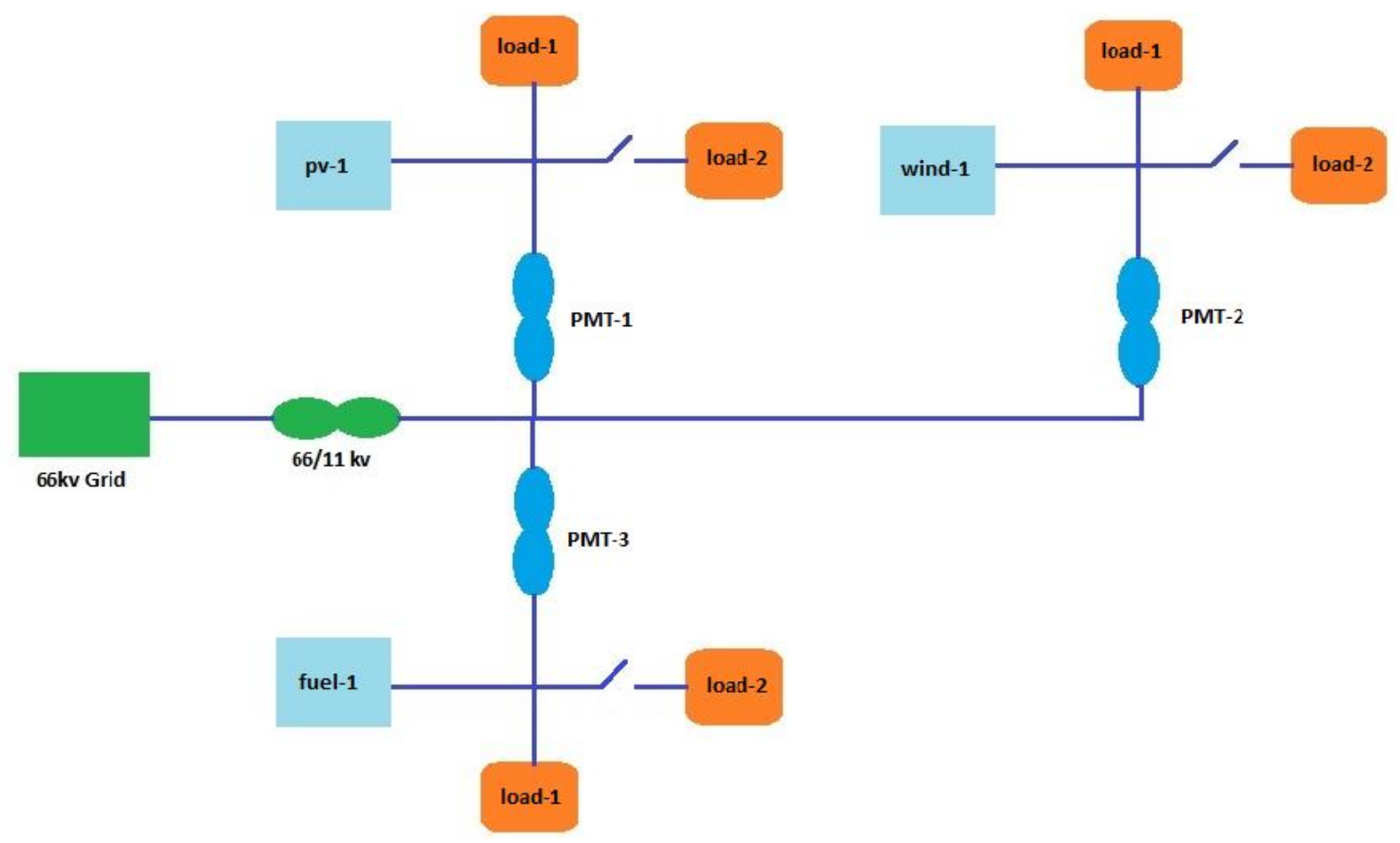

Fig. 2. 1- Solar PV Unit, 1 - Wind Mill and 1 - Fuel Cell 


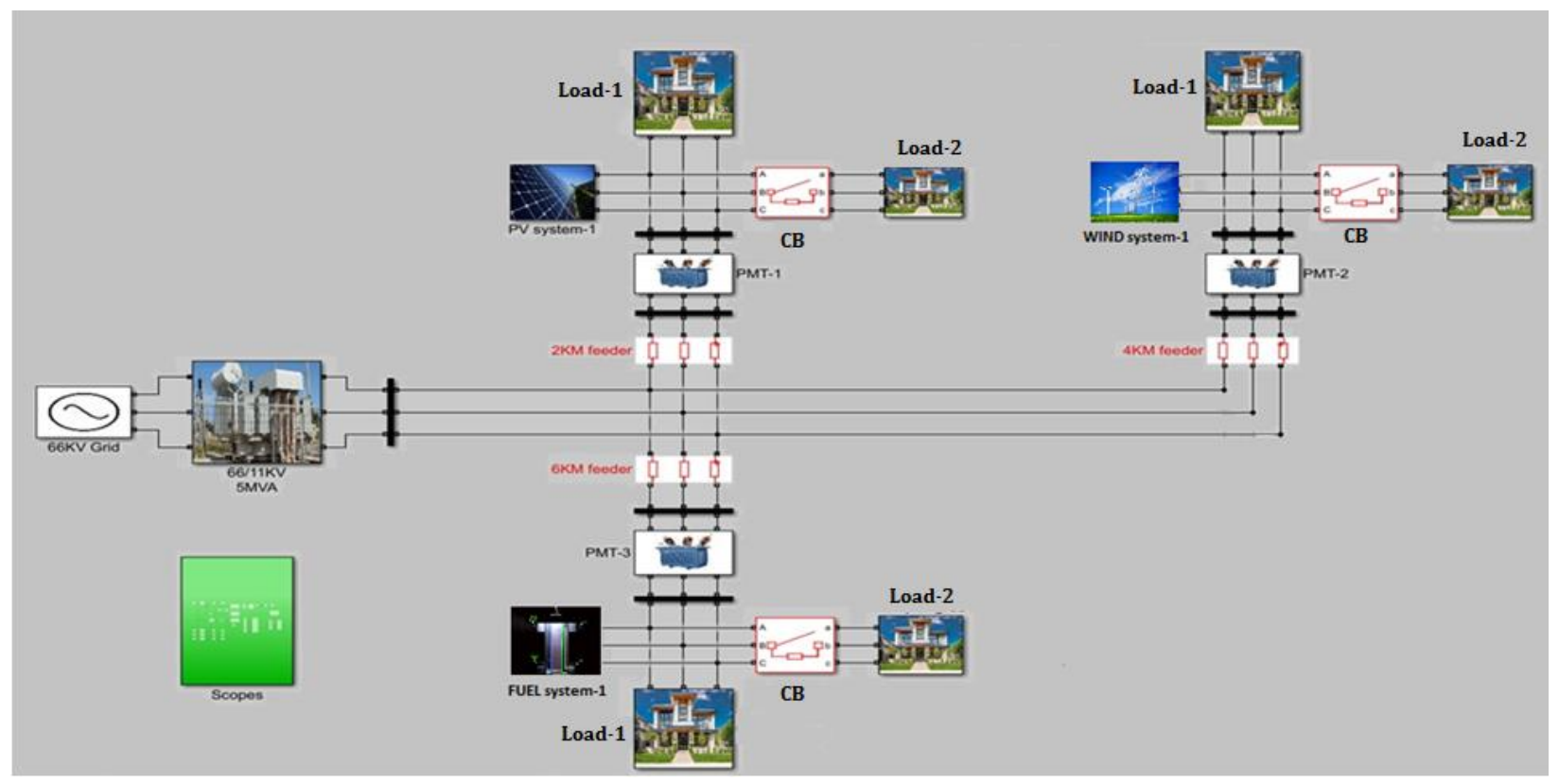

Fig. 3. Matlab-Simulink Model

Table 1. Specification of Model Components

\begin{tabular}{|c|l|}
\hline \multicolumn{1}{|c|}{ Grid } & $\begin{array}{l}\text { Phase to phase voltage }-66 \mathrm{kV} \\
\text { Frequency }-50 \mathrm{~Hz}\end{array}$ \\
\hline Transformer & $\begin{array}{l}\text { Power }-5 \mathrm{MVA} \\
\text { Input voltage }-66 \mathrm{kV} \\
\text { Output voltage }-11 \mathrm{kV}\end{array}$ \\
\hline Transformer & $\begin{array}{l}\text { Power }-100 \mathrm{KVA} \\
\text { Input voltage }-11 \mathrm{kV} \\
\text { Output voltage }-415 \mathrm{~V}\end{array}$ \\
\hline Circuit Breaker & $\begin{array}{l}\text { Switching time }-0.5 \\
\text { Circuit breaker resistance }-0.01\end{array}$ \\
\hline Load & $\begin{array}{l}\text { Power }-30 \mathrm{~kW} \\
\text { Voltage- } 415 \\
\text { Frequency }-50 \mathrm{~Hz}\end{array}$ \\
\hline
\end{tabular}


MATLAB Simulink is used to simulate and verify the proposed system whose single line diagram (SLD) is given in Figure 3. Load-1 is a base demand and Load-1 plus Load-2 is demand the peak hours.

\section{Simulation Cases of virtual power plant}

Three different cases are analyzed to understand the performance of virtual power plant.

1) Case 1: A sudden increase in load. (55 kW)

2) Case 2: A sudden decrease in load. $(60 \mathrm{~kW})$

3) Case 3: The increase followed by a decrease in a load on buses. (50 kW)

\section{Results \& Discussion}

\section{Sudden increase in load ( $55 \mathrm{~kW}$ )}

1.1 Sudden Increase in Load Uncontrolled Injection.
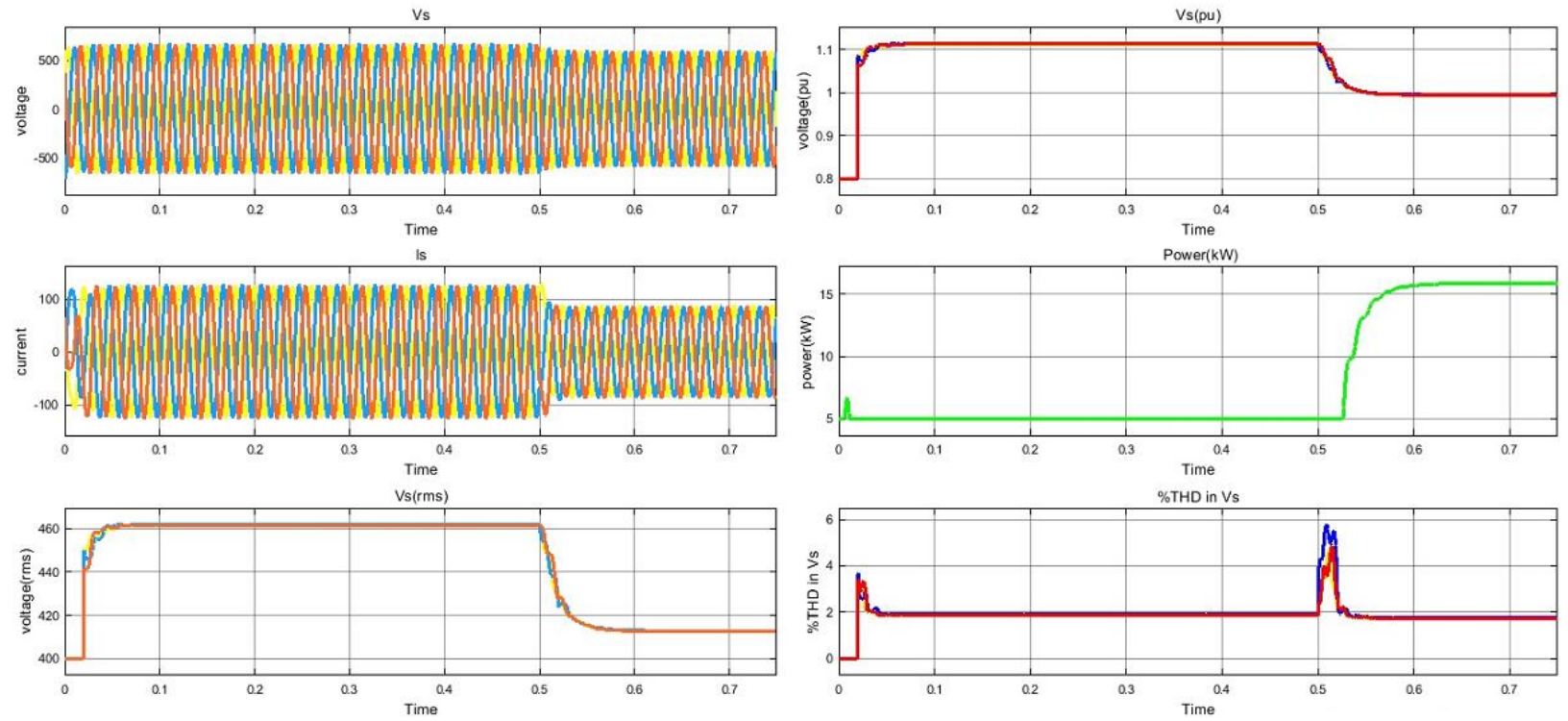

Fig.4 Voltage, current, power and THD waveform without control 
As no control is provided the solar PV, wind mills and fuel cell module have acted abnormally and not provided the desired response. It is to be noted that the \%THD is well within the limits (5\%) and this is due to the filter provided.
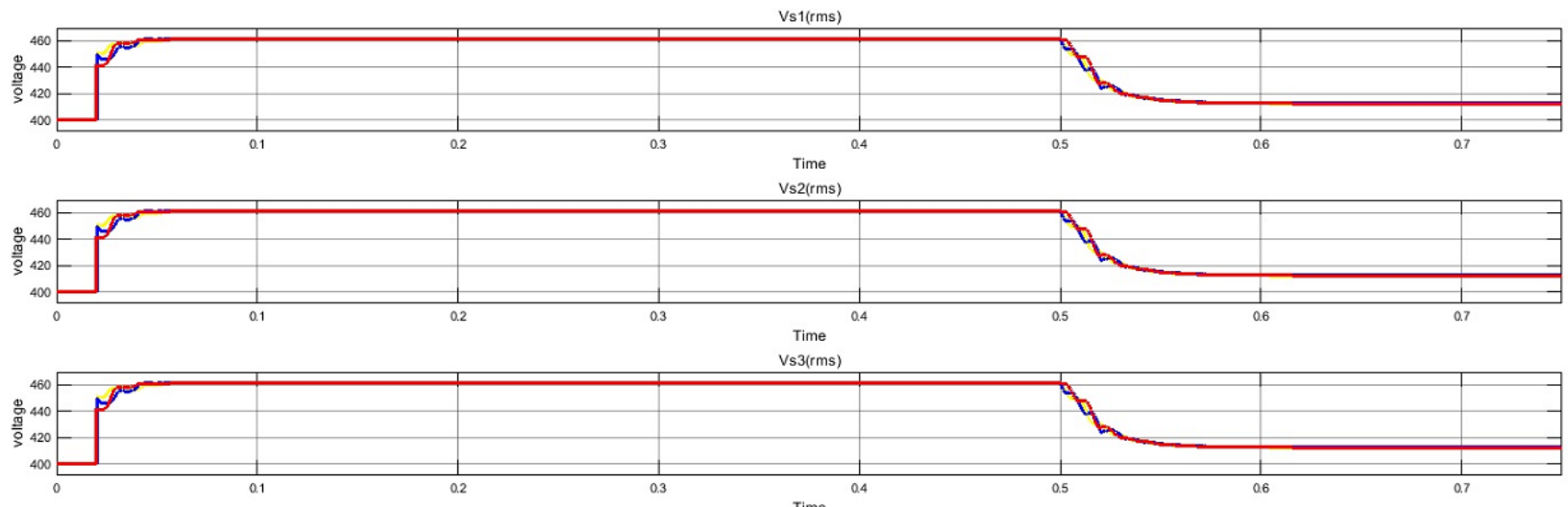

Fig. 5 Feeder Voltages

The waveforms shown in the figures 4 and 5 when we simulated an increase in load of a grid-connected solar PV, wind mills and fuel cell module. It was not provided any control mechanism and it is evident as the terminal voltage is near to the desired value. At $t=0.5$ sec the load on the branch is increased and as expected, the terminal voltage has fallen.

\subsection{Sudden Increase in Load Controlled Injection.}
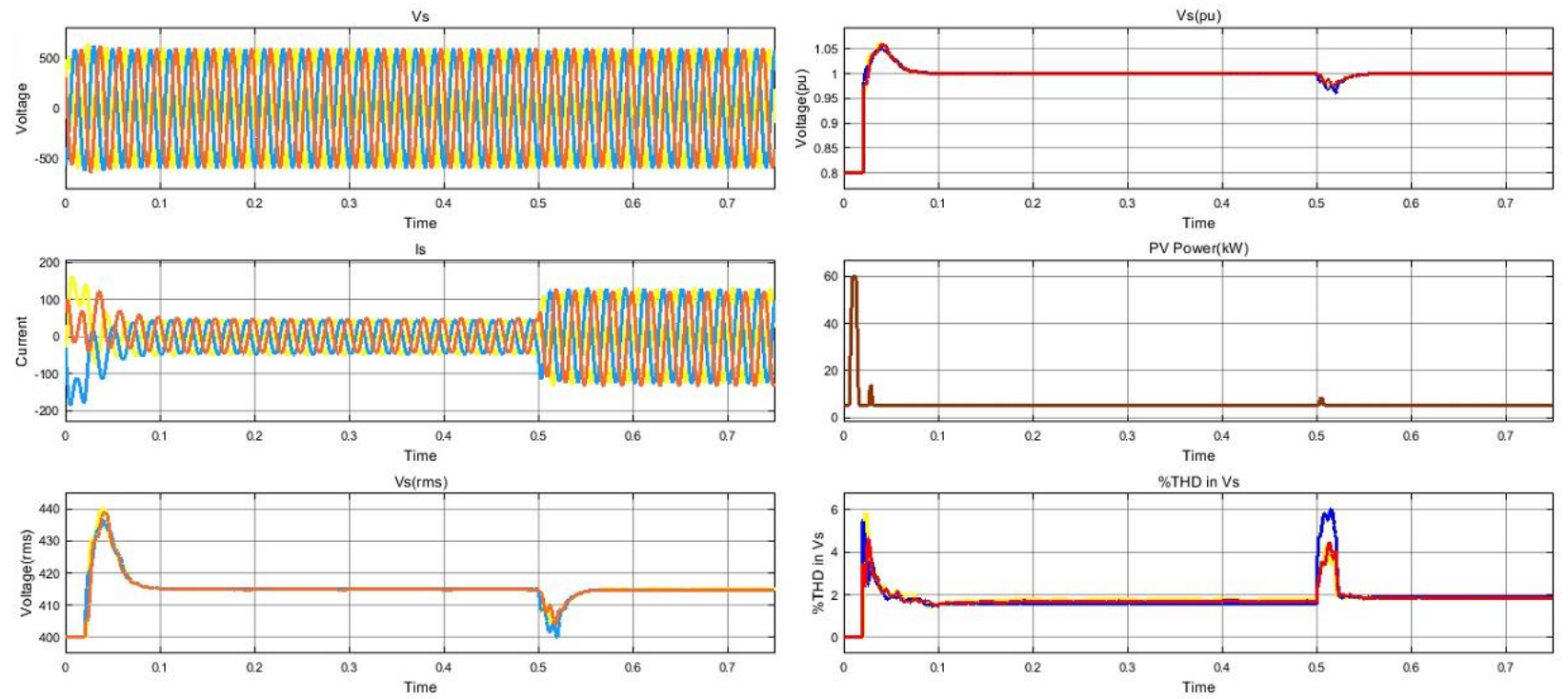

Fig.6 Voltage, current, power and THD waveform with control 
The above results it can be seen that the difference made by employing close loop control strategy. As the load has increased the current injection also increased and terminal voltage remained constant.
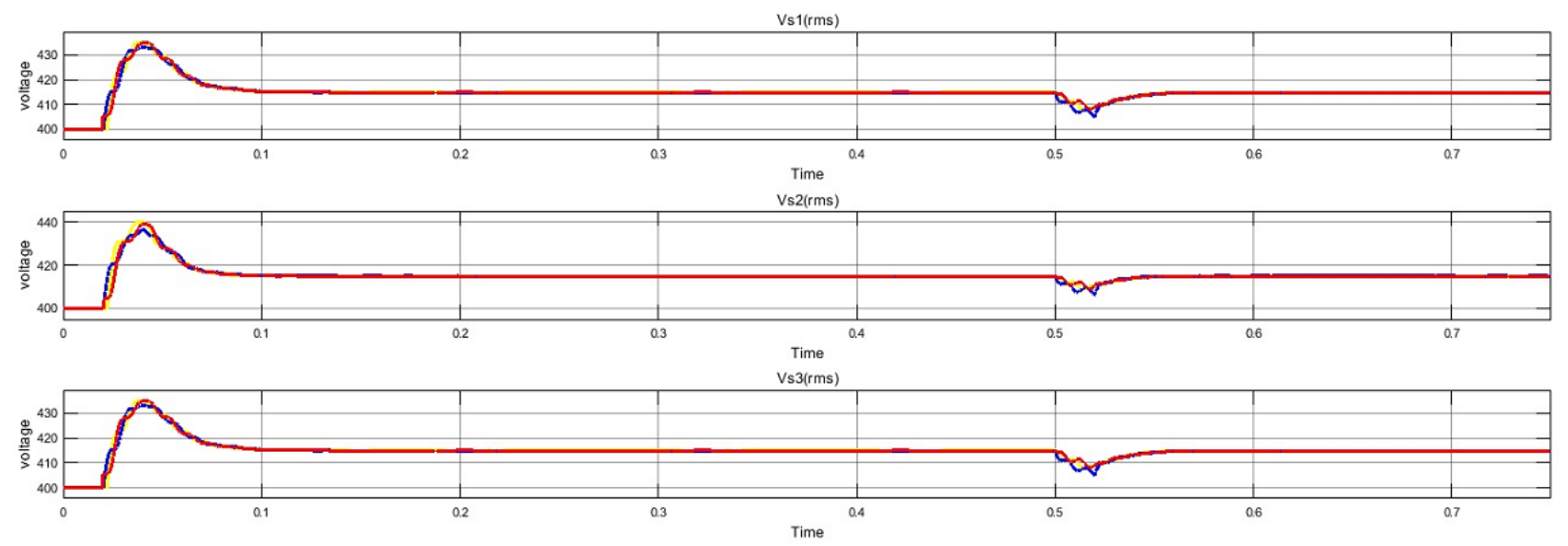

Fig. 7. Feeder Voltages

The above results are obtained for the same increase in load, the only difference here is it was employed a closed loop PID controller and it has performed satisfactorily. Even after the increase in load at $\mathrm{t}=0.5 \mathrm{sec}$ the terminal voltage remained stable at desired $415 \mathrm{~V}$.

\section{Sudden decrease in load. $(60 \mathrm{~kW})$}

2.1 Sudden Decrease in Load Uncontrolled Injection
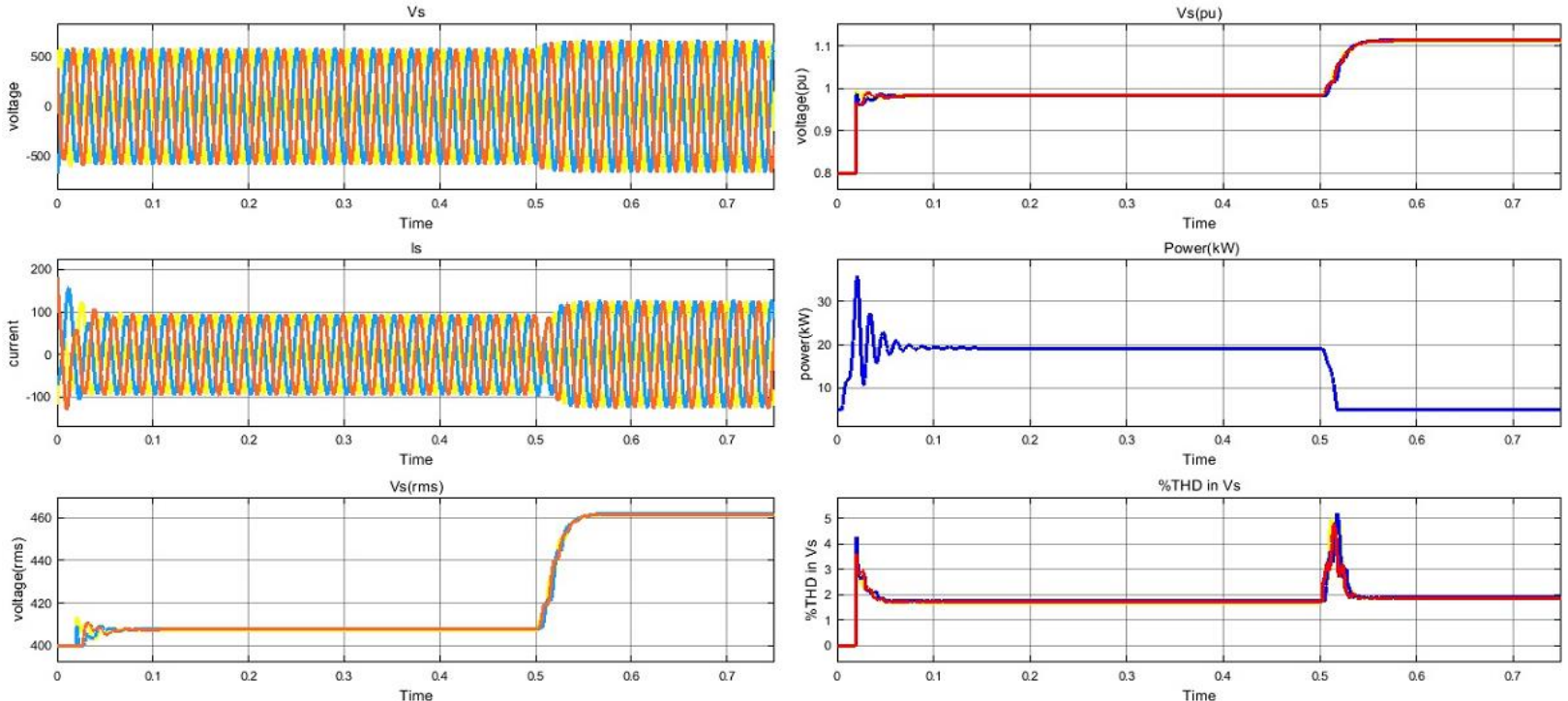
Fig.8 Voltage, current, power and THD waveform with uncontrolled

The above results the close loop-control is not provided in this system. The solar PV, wind mills and fuel cell module did not work sufficiently and do not provide the desired response.
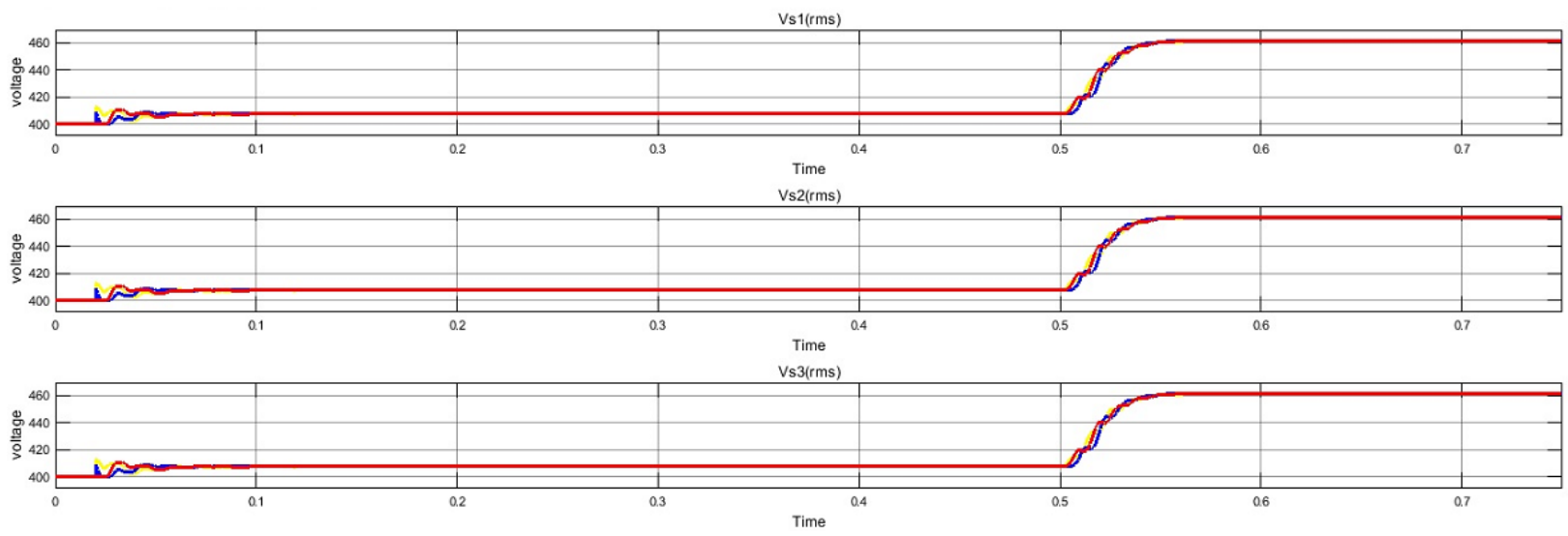

Fig. 9. Feeder Voltages

The results obtained when there was a fall in demand of a grid-connected solar PV, wind mills and fuel cell module. Any control mechanism was not provided in the system and it is evident as the terminal voltage is now near to the desired value of $415 \mathrm{~V}$. At $\mathrm{t}=0.5$ sec the load on the branch is decreased and as expected the terminal voltage has increased.

\subsection{Sudden Decrease in Load Controlled Injection}
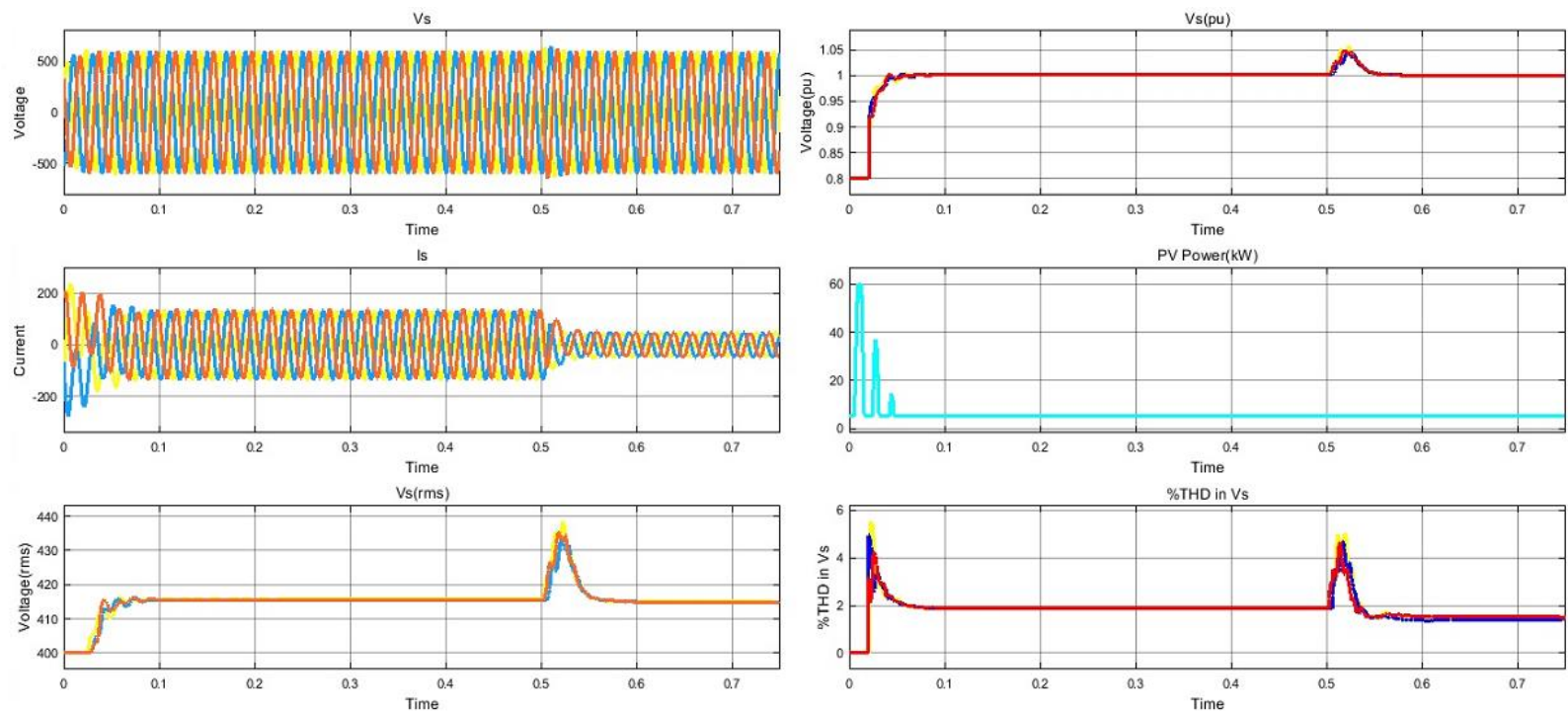

Fig.10 voltage, current, power and THD waveform with control 
The result show the system parameters when a close loop control strategy is employed. It is evident that the controller has performed satisfactorily and has maintained $415 \mathrm{~V}$ despite the fall in demand.
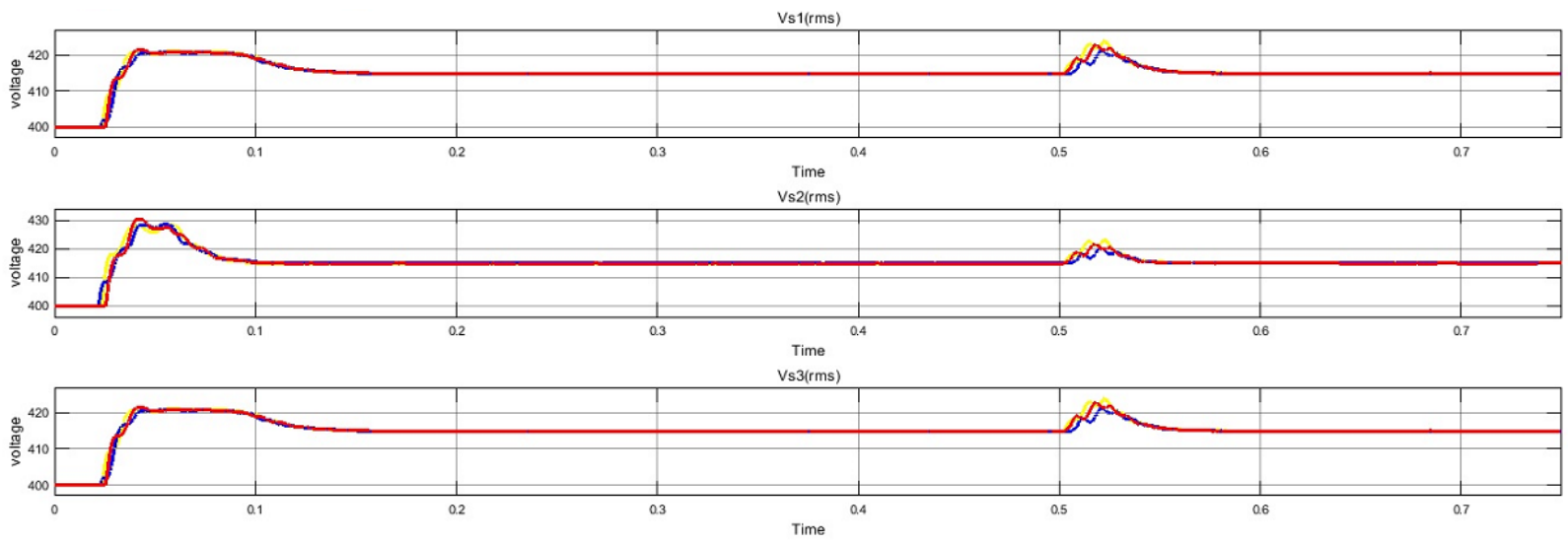

Fig. 11. Feeder Voltages

The results are obtained for the same decrease in demand, the only difference here is that the closed-loop PID controller is employed and it has performed satisfactorily. Despite decrease in load at $\mathrm{t}=0.5 \mathrm{sec}$, the terminal voltage remained stable at desired $415 \mathrm{~V}$ instead of rising as seen with the uncontrolled case.

3. The increase followed by a decrease in a load on buses. (50 kW) 
3.1 Increase Followed by Decrease in a Load on Buses Uncontrolled Injection
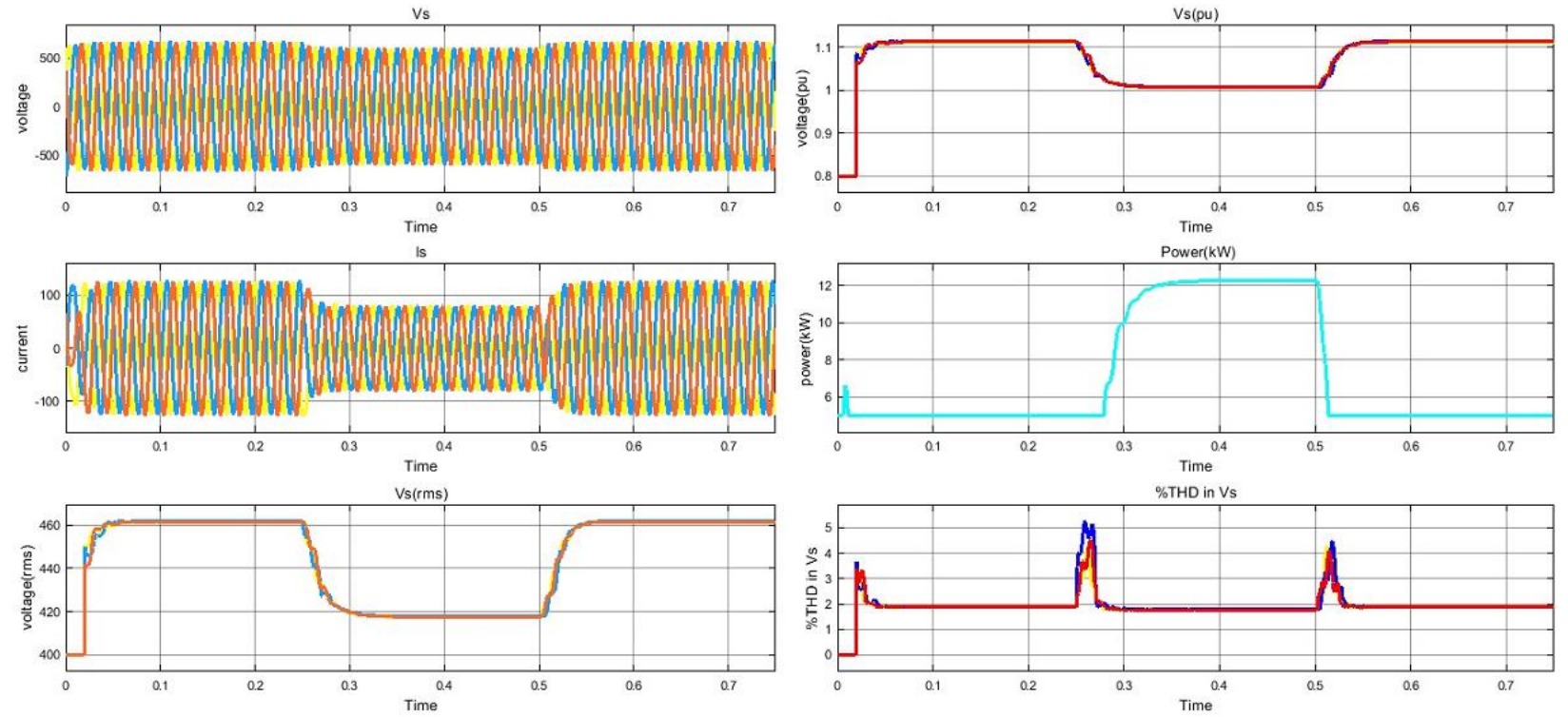

Fig.12 voltage, current, power and THD waveform with uncontrolled

The load is increased at $\mathrm{t}=0.25 \mathrm{~s}$ and then decreased at $\mathrm{t}=0.5 \mathrm{~s}$.
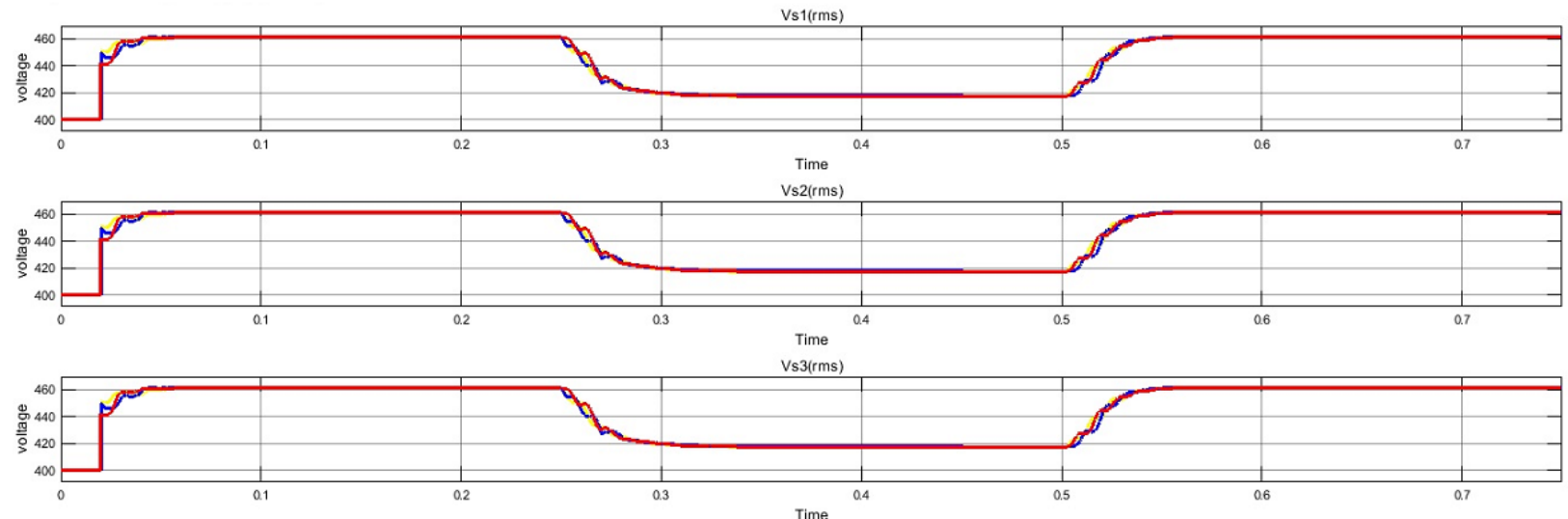

Fig. 13. Feeder Voltages

We can see that as the load increases at $t=0.25 \mathrm{sec}$, the voltage has decreased. Now the load is decreased at $\mathrm{t}=0.5 \mathrm{sec}$ and the voltage has increased. 
3.2 Increase Followed by Decrease in a Load on Buses Controlled Injection
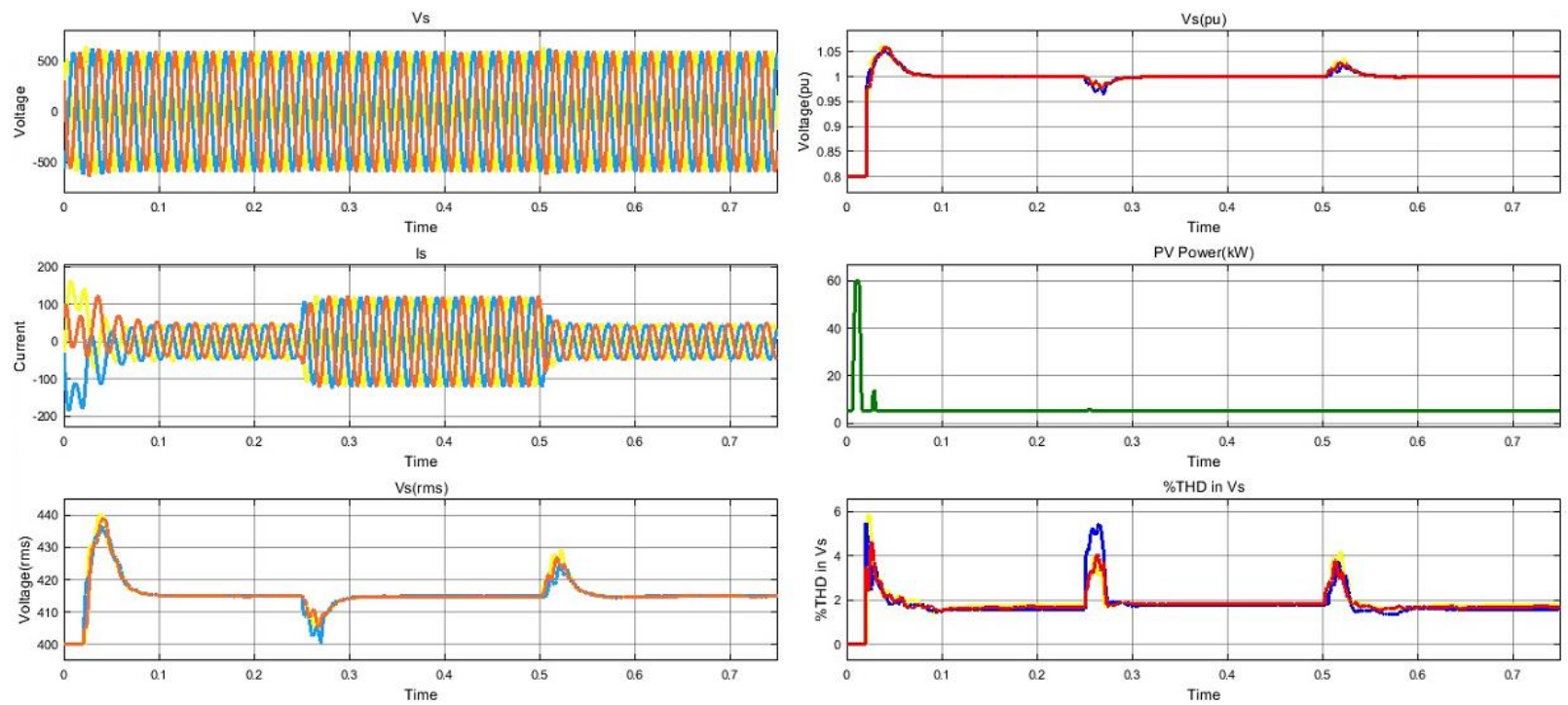

Fig.14 voltage, current, power and THD waveform with control

Now the PID controller is employed so the injection is controlled as a result no abnormalities are found and it is to be noted that the \%THD is well within the limits (5\%) and this is due to the filter provided.
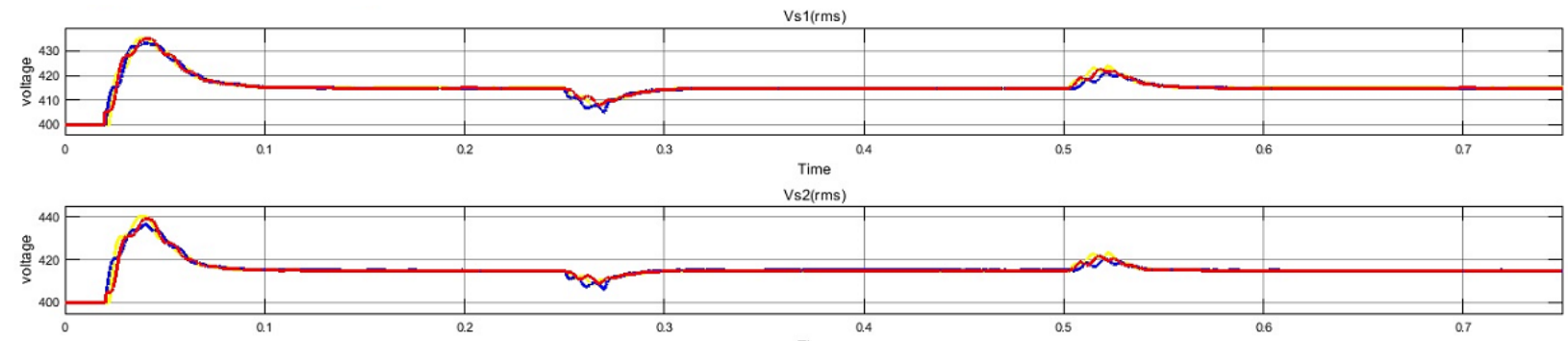

Time

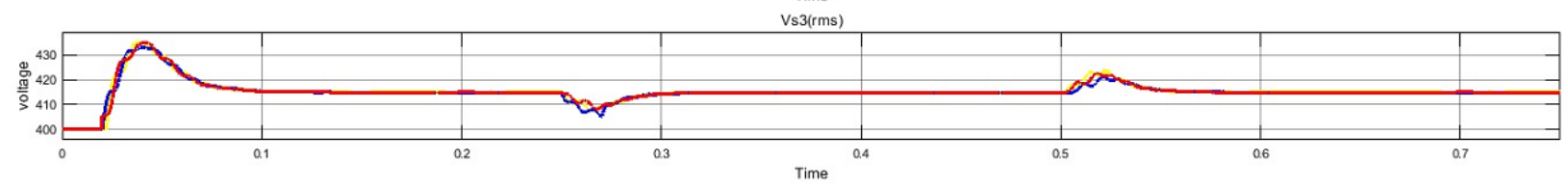

Fig. 15. Feeder Voltages

At 0.25 seconds, the load is increased and the voltage dip occurred which is soon brought to $415 \mathrm{~V}$ because of the closed loop control. Later, at 0.5 seconds, the load is decreased suddenly and a voltage rise is seen in the waveform which is then controlled and brought back to normal value, $415 \mathrm{~V}$, which shows that the controller is working fine. 


\section{Conclusion}

* When conventional peak load plants like hydro and gas turbine plants are used to supply peak demand for small time their operation is not economical and their response to the variation is also slow.

* While supplying unplanned peak demands, virtual power plant is the most economical option.

* In an uncontrolled system, the voltage fluctuation is between 0.983 pu to $1.113 \mathrm{pu}$ and with controlled injection by solar PV, wind mill and fuel cell the voltage remains 1 pu with increase or decrease of load.

* It is also observed that voltage profile on a feeder is improved by the use of virtual power plant.

\section{References}

1. H. A. Khan, H. C. IU and V. Sreeram, "Active and Reactive Power Control of the Electronically Interfaced DG Sources for the Realization of a Virtual Power Plant"IEEE Industrial Electronics Society Nov.2011.

2. Xavier Dominguez, Marcelo Pozo, Carlos Gallardo, Leonardo Ortega," Active Power Control of a Virtual Power Plant" IEEE Transactions on Active Power Control of a Virtual Power Plant Jan. 2016.

3. Lucian Ioan DULĂU, Mihail ABRUDEAN, Dorin BICĂ, "Distributed Generation and Virtual Power Plants" 49th International Universities Power Engineering Conference (UPEC) Sep 2014.

4. Setu Paghdar, Eves Sipai, Kaushal Ambasana, Priyesh J. Chauhan, "Active and Reactive Power Control of Grid Connected Distributed Generation System" IEEE 2017 Second International Conference on Electrical, Computer and Communication Technologies (ICECCT).

5. Veera Joshi, Bhinal Mehta and Siddharth Joshi, "Active and Reactive Power Control of Photovoltaic Power Plant Under Normal and Abnormal Grid Conditions" Springer 
International Conference on Power, Control and Communication Infrastructure Volume 604 July 2019.

6. Jose Restrepo, Xavier Dominguez, Jhonny Barzola, Isabel Quinde," Inverter Control for Power Injection from PV Sources in Microgrids Under Unbalanced Power Grid and Load Conditions" IEEE Transactions on Power Electronics Oct.2018.

7. Solar Cells. chemistryexplained.com.

8. https://www.toppr.com/guides/science/energy/windmills-and-its-applications/

9. https://mnre.gov.in/.

10. Naina P M, Haile-Selassie Rajamani and K. S. Swarup, "Modelling and simulation of virtual power plant in energy management system applications" IEEE 2017 7th International Conference on Power Systems (ICPS). 